\title{
Faktor Risiko yang Berpengaruh terhadap Kejadian Berat Badan Lahir Rendah di RSUP Dr. M. Djamil Padang
}

\author{
Sagung Adi Sresti Mahayana1, Eva Chundrayetti², Yulistini ${ }^{3}$
}

\begin{abstract}
Abstrak
Berat Badan Lahir Rendah (BBLR) adalah bayi yang lahir dengan berat badan kurang dari $2500 \mathrm{~g}$. BBLR merupakan prediktor utama angka kesakitan dan kematian bayi. Tujuan penelitian ini adalah untuk menentukan faktor risiko ibu, plasenta, janin dan lingkungan yang berpengaruh terhadap kejadian BBLR. Penelitian ini bersifat analitik dengan desain cross-sectional dengan mengumpulkan data retrospektif rekam medis ibu yang melahirkan bayi BBLR di RSUP Dr. M. Djamil Padang dari Januari sampai Desember 2012. Pada 72 sampel yang didapatkan, faktor risiko janin dengan jenis kelamin laki-laki $(61,1 \%)$ dan status sosioekonomi rendah $(52,8 \%)$ memiliki proporsi yang lebih besar pada kejadian BBLR. Analisis bivariat chi-square menunjukkan faktor risiko anemia $(p=0,001)$ dan kelainan plasenta $(p=0,049)$ memiliki hubungan statistik yang signifikan terhadap kejadian BBLR prematur dan dismatur. Pengaruh terbesar secara statistik terdapat pada faktor risiko anemia $(p=0,001)$ dan paritas $(p=0,022)$ pada analisis multivariat regresi logistik. Anemia, kelainan plasenta dan paritas merupakan faktor risiko yang berpengaruh terhadap kejadian BBLR prematur dan dismatur di RSUP Dr. M. Djamil Padang.
\end{abstract}

Kata kunci: BBLR, prematur, dismatur, faktor risiko

\begin{abstract}
Low birthweight (LBW) is a birth weight under $2500 \mathrm{~g}$. LBW is a major predictor of infant morbidity and mortality. The objective of this study was to determine maternal, placental, fetal and environmental risk factors that influencing $\angle B W$. This was a cross-sectional study by obtaining retrospective datas from medical records of mother who delivered LBW babies at RSUP Dr. M. Djamil Padang from January until December 2012 period. Male fetal sex (61.1\%) and low socioeconomic status (52.8\%) were found in high rates on total 72 cases of LBW. Chi-square test showed anemia $(p=0.001)$ and placental abnormalities $(p=0.049)$ were statistically significant in LBW with premature and dysmature. Logistic regression test indicates anemia $(p=0.001)$ and parity $(p=0.022)$ are statistically influence LBW. Anemia, placental abnormalities and parity are significant risk factors resulting low birth weight babies with premature and dismature in RSUP Dr. M. Djamil Padang.
\end{abstract}

Keywords: $L B W$, premature, dysmature, risk factors

\begin{abstract}
Affiliasi penulis: 1. Pendidikan Dokter FK UNAND (Fakultas Kedokteran Universitas Andalas Padang), 2. Bagian IImu Kesehatan Anak FK UNAND/RS Dr. M. Djamil Padang, 3. Bagian Pendidikan Kedokteran FK UNAND.

Korespondensi: Sagung Adi Sresti Mahayana, E-mail: adismahayana@yahoo.com, Telp: +628127588825
\end{abstract}

\section{PENDAHULUAN}

BBLR (Berat Badan Lahir Rendah) diartikan sebagai bayi yang lahir dengan berat badan kurang dari 2500 gram. BBLR merupakan prediktor tertinggi angka kematian bayi, terutama dalam satu bulan pertama kehidupan. Berdasarkan studi epidemiologi, bayi BBLR mempunyai risiko kematian 20 kali lipat lebih besar di bandingkan dengan bayi yang lahir dengan berat badan normal. ${ }^{1,2}$

Lebih dari 20 juta bayi di seluruh dunia lahir dengan BBLR dan $95.6 \%$ bayi BBLR lahir di negara yang sedang berkembang, contohnya di Indonesia. Menurut Survey Demografi dan Kesehatan Indonesia tahun 2002-2003, angka prevalensi BBLR di Indonesia masih tergolong tinggi yaitu $9 \%$ dengan sebaran yang cukup bervariasi pada masing-masing provinsi. Angka 
terendah tercatat di Bali $(5,8 \%)$ dan tertinggi di Papua (27\%), sedangkan di Provinsi Sumatera Barat berkisar $7 \% .^{1,3}$

Di Kota Padang, angka kematian bayi pada tahun 2009 tercatat 107 kasus dari 16.449 kelahiran hidup dan BBLR menjadi penyebab nomor satu dari kematian bayi dengan jumlah 28 kasus (26,2\%). Pada tahun 2011, dari 16.584 kelahiran hidup, tercatat 142 bayi lahir dengan BBLR. ${ }^{4}$

BBLR disebabkan oleh usia kehamilan yang pendek (prematuritas), IUGR (Intra Uterine Growth Restriction) yang dalam bahasa Indonesia disebut Pertumbuhan Janin Terhambat (PJT) atau keduanya. Kedua penyebab ini dipengaruhi oleh faktor risiko, seperti faktor ibu, plasenta, janin dan lingkungan. Faktor risiko tersebut menyebabkan kurangnya pemenuhan nutrisi pada janin selama masa kehamilan. ${ }^{2,5-7}$

Bayi dengan berat badan lahir rendah umumnya mengalami proses hidup jangka panjang yang kurang baik. Apabila tidak meninggal pada awal kelahiran, bayi BBLR memiliki risiko tumbuh dan berkembang lebih lambat dibandingkan dengan bayi yang lahir dengan berat badan normal. Selain gangguan tumbuh kembang, individu dengan riwayat BBLR mempunyai faktor risiko tinggi untuk terjadinya hipertensi, penyakit jantung dan diabetes setelah mencapai usia 40 tahun. ${ }^{2,8}$

Pada masa sekarang ini, sudah dikembangkan tatalaksana awal terhadap bayi BBLR dengan menjaga suhu optimal bayi, memberi nutrisi adekuat dan melakukan pencegahan infeksi. Meskipun demikian, masih didapatkan $50 \%$ bayi BBLR yang meninggal pada masa neonatus atau bertahan hidup dengan malnutrisi, infeksi berulang dan kecacatan perkembangan neurologis. Oleh karena itu, pencegahan insiden BBLR lebih diutamakan dalam usaha menekan Angka Kematian Bayi. ${ }^{9}$

Dalam rangka mencapai target Millenium Development Goals yang ke IV yaitu menurunkan angka kematian anak terutama di negara berkembang, perlu dilakukan upaya pencegahan kejadian BBLR di masa mendatang, salah satunya dengan melakukan pengawasan ketat terhadap faktor-faktor risiko yang mempengaruhi kejadian BBLR. Berdasarkan data diatas, maka perlu diteliti faktor-faktor risiko yang berpengaruh terhadap kejadian BBLR di RSUP Dr. M. Djamil Padang.

\section{METODE}

Penelitian ini merupakan studi analisis data retrospektif dengan desain cross-sectional yang dilakukan di Sub Bagian Rekam Medik RSUP Dr. M. Djamil Padang dari November 2012 sampai Maret 2013. Populasi penelitian adalah seluruh ibu yang melahirkan bayi BBLR yang terdata di rekam medis RSUP Dr. M. Djamil Padang periode Januari 2012 Desember 2012. Sampel pada penelitian ini diambil dengan teknik total sampling yaitu seluruh populasi dinyatakan sebagai sampel. Sampel yang memenuhi kriteria penelitian adalah ibu melahirkan bayi dengan diagnosis BBLR secara klinis di RSUP Dr. M. Djamil Padang, sedangkan subjek dengan data rekam medis yang tidak lengkap tidak dapat dijadikan sampel penelitian. Seluruh data sekunder rekam medis pasien BBLR RSUP Dr. M. Djamil Padang diambil datanya, kemudian diolah secara manual berdasarkan kelompok faktor risiko yang diteliti. Data yang diambil adalah data BBLR prematur atau dismatur, faktor risiko ibu yaitu usia ibu saat melahirkan, jarak kelahiran, paritas teratogen, penyakit medis ibu, anemia, riwayat obstetris buruk dan status gizi ibu. Faktor plasenta meliputi adanya kelainan plasenta atau tidak; faktor janin yaitu jenis kelamin janin, jenis gestasi dan kelainan congenital. Faktor lingkungan yaitu ketinggian tempat tinggal, pendidikan ibu dan status sosioekonomi. Data dianalisis dengan menggunakan program aplikasi komputer. Analisis data meliputi analisis univariat, bivariat dan multivariat.

\section{HASIL}

Penelitian ini dilakukan terhadap 72 sampel yang memenuhi kriteria inklusi sebagai subjek penelitian pada periode Januari 2012 - Desember 2012. Pada pengambilan data didapatkan jumlah sampel keseluruhan sebanyak 135 kasus dengan eksklusi sebanyak 63 sampel. Data yang diperoleh dikelompokkan dan ditabulasikan sesuai dengan karakteristik masing-masing. Bayi BBLR dengan kelahiran prematur dan dismatur didapatkan hasil sebagai berikut: 
Tabel 1. Distribusi frekuensi kejadian BBLR prematur dan dismatur di RSUP Dr. M. Djamil Padang periode Januari 2012 - Desember 2012

\begin{tabular}{ccc}
\hline BBLR & $\mathbf{n}$ & $\%$ \\
\hline Prematur & 37 & 51,4 \\
Dismatur & 35 & 48,6 \\
\hline Total & $\mathbf{7 2}$ & $\mathbf{1 0 0}$ \\
\hline
\end{tabular}

Tabel 1 diatas memperlihatkan jumlah BBLR prematur dan dismatur yang terdata di RSUP Dr. M. Djamil Padang periode Januari 2012 - Desember 2012 hampir sama banyak. Kejadian BBLR prematur tercatat sebanyak 37 kasus $(51,4 \%)$ dari semua kasus BBLR.

Pada Tabel 2 terlihat bahwa faktor risiko dari ibu ditemukan jumlah persentasi yang cukup besar untuk keadaan berisiko terjadinya BBLR, yaitu faktor risiko paritas, dimana terdapat keadaan multiparitas (jumlah anak 2-4 orang) sebesar 58,3\%. Sebaliknya ditemukan jumlah persentasi yang lebih kecil untuk keadaan ibu yang memiliki faktor risiko, seperti: usia berisiko $(29,2 \%)$, jarak kelahiran rapat $(18,1 \%)$ dan anemia (36,1\%). Keadaan berisiko lainnya yang jumlah persentasinya kecil ditemukan juga pada faktor penyakit medis ibu (41,7\%), riwayat obstetri buruk $(20,8 \%)$ dan status gizi ibu (18,1\%). Bahkan untuk faktor teratogen ditemukan $0 \%$ pada ibu yang melahirkan bayi BBLR.

Faktor risiko kelainan plasenta hanya ditemukan pada 19,4\% ibu dengan bayi BBLR, yaitu plasenta previa sebanyak $15,3 \%$ dan KPD sebanyak $4,2 \%$. Bayi BBLR yang memiliki faktor risiko persentasi kecil juga ditemukan pada faktor kelahiran kembar sebesar $23,6 \%$ dan kelainan kongenital sebesar 2,8\%. Hanya faktor jenis kelamin yang berisiko terjadi BBLR yaitu laki-laki lebih besar persentasinya yaitu $61,1 \%$.

Dari segi faktor risiko lingkungan, didapatkan hasil sebanyak $11,1 \%$ ibu yang melahirkan bayi BBLR tinggal di dataran tinggi $>700$ mdpl, 20,8\% ibu berpendidikan rendah dan $52,8 \%$ ibu memiliki status sosioekonomi yang rendah. Hanya faktor sosioekonomi lemah yang menunjukkan angka cukup besar untuk kejadian BBLR.
Tabel 2. Distribusi faktor risiko BBLR di RSUP Dr. M. Djamil Padang dari Januari 2012 - Desember 2012

\begin{tabular}{|c|c|c|c|}
\hline \multicolumn{2}{|c|}{ Variabel } & $n$ & $\%$ \\
\hline \multirow{2}{*}{$\begin{array}{l}\text { Usia ibu } \\
(<20 \text { th dan }>35 \\
\text { Th) }\end{array}$} & Berisiko & 21 & 29,2 \\
\hline & Tidak berisiko & 51 & 70,8 \\
\hline \multirow{5}{*}{ Paritas } & $\mathrm{GMP}^{*}$ & & \\
\hline & (>4 anak) & 4 & 5,6 \\
\hline & & 42 & 58,3 \\
\hline & (2-4 anak) & 26 & 36,1 \\
\hline & (1 anak) & & \\
\hline \multirow{2}{*}{$\begin{array}{c}\text { Jarak kelahiran } \\
\qquad(<2 \text { th })\end{array}$} & berisiko & 13 & 18,1 \\
\hline & tidak berisiko & 59 & 81,9 \\
\hline Anemia & Anemis & 26 & 36,1 \\
\hline$(\mathrm{Hb}<11 \mathrm{~g} / \mathrm{dl})$ & Tidak anemis & 46 & 63,9 \\
\hline
\end{tabular}

\begin{tabular}{lccc}
\hline \multicolumn{1}{c}{ Penyakit ibu } & & & \\
(hipertensi kronis, & Ada & 30 & 41,7 \\
preeklamsia, & Tidak ada & 42 & 58,3 \\
diabetes, infeksi) & & &
\end{tabular}

\begin{tabular}{|c|c|c|c|}
\hline $\begin{array}{c}\text { Teratogen } \\
\text { (rokok, alkohol, } \\
\text { obat) }\end{array}$ & $\begin{array}{c}\text { Ada } \\
\text { Tidak ada }\end{array}$ & $\begin{array}{c}0 \\
72\end{array}$ & $\begin{array}{c}0 \\
100\end{array}$ \\
\hline $\begin{array}{l}\text { Riwayat obstetr } \\
\quad \text { buruk } \\
\text { (abortus, pernah } \\
\text { melahirkan bayi } \\
\text { BBLR) }\end{array}$ & $\begin{array}{c}\text { Ada } \\
\text { Tidak ada }\end{array}$ & $\begin{array}{l}15 \\
57\end{array}$ & $\begin{array}{l}20,8 \\
79,2\end{array}$ \\
\hline $\begin{array}{l}\text { Status gizi ibu } \\
\quad \text { KEK } \\
\text { (Kurang Energi } \\
\text { Kronis) }\end{array}$ & $\begin{array}{l}\text { KEK }^{* * * *} \\
\text { Tidak KEK }\end{array}$ & $\begin{array}{l}13 \\
59\end{array}$ & $\begin{array}{l}18,1 \\
81,9\end{array}$ \\
\hline $\begin{array}{l}\text { Kelainan } \\
\text { plasenta }\end{array}$ & $\begin{array}{c}\text { Plasenta } \\
\text { previa } \\
\text { Solusio } \\
\text { plasenta } \\
\text { KPD } \\
\text { Normal }\end{array}$ & $\begin{array}{c}11 \\
0 \\
3 \\
58\end{array}$ & $\begin{array}{c}15,3 \\
0 \\
4,2 \\
80,6\end{array}$ \\
\hline $\begin{array}{c}\text { Jenis kelamin } \\
\text { janin }\end{array}$ & $\begin{array}{c}\text { Laki-laki } \\
\text { Perempuan }\end{array}$ & $\begin{array}{l}44 \\
28\end{array}$ & $\begin{array}{l}61,1 \\
38,9\end{array}$ \\
\hline Jenis gestasi & $\begin{array}{l}\text { Multipel } \\
\text { Tunggal }\end{array}$ & $\begin{array}{l}17 \\
55\end{array}$ & $\begin{array}{l}23,6 \\
76,4\end{array}$ \\
\hline $\begin{array}{c}\text { Kelainan } \\
\text { kongenital }\end{array}$ & $\begin{array}{c}\text { Ada } \\
\text { Tidak ada }\end{array}$ & $\begin{array}{c}2 \\
70\end{array}$ & $\begin{array}{c}2,8 \\
97,2\end{array}$ \\
\hline $\begin{array}{c}\text { Ketinggian } \\
\text { tempat tinggal }\end{array}$ & $\begin{array}{c}\text { Berisiko } \\
\text { Tidak berisiko }\end{array}$ & $\begin{array}{c}8 \\
64\end{array}$ & $\begin{array}{l}11,1 \\
88,9\end{array}$ \\
\hline Pendidikan ibu & $\begin{array}{l}\text { Rendah } \\
\text { Sedang } \\
\text { Tinggi }\end{array}$ & $\begin{array}{c}15 \\
48 \\
9\end{array}$ & $\begin{array}{l}20,8 \\
66,7 \\
12,5\end{array}$ \\
\hline $\begin{array}{c}\text { Status } \\
\text { sosioekonomi }\end{array}$ & $\begin{array}{l}\text { Rendah } \\
\text { Sedang } \\
\text { Tinggi }\end{array}$ & $\begin{array}{c}38 \\
28 \\
6\end{array}$ & $\begin{array}{c}52,8 \\
38,9 \\
8,3\end{array}$ \\
\hline
\end{tabular}


Pada analisis bivariat chi-square, ditentukan hubungan antara faktor-faktor risiko pada ibu dan plasenta dengan kejadian BBLR prematur dan dismatur: Tabel 3 memperlihatkan faktor paritas, kelainan plasenta, pendidikan ibu dan status sosioekonomi memiliki sebaran distribusi frekuensi responden yang tidak merata dan terdapat jumlah $<5$ responden pada beberapa sel sehingga nilai $p$ tidak dapat diolah berdasarkan tabel distribusi frekuensi. Oleh sebab itu, dilakukan supresi tabel 2x2 untuk mendapatkan nilai $\mathrm{p}$ yang valid pada masing-masing variabel. Paritas dibagi atas kelompok primipara serta multipara dan grandemultipara, kelainan plasenta dikelompokkan menjadi ada dan tidak ada, status sosioekonomi dikelompokkan menjadi rendah dan tinggi serta tingkat pendidikan ibu dikategorikan berdasarkan wajib belajar sembilan tahun yaitu kategori SD-SMP (Sekolah Dasar-Sekolah Menengah Pertama) dan SMA-PT (Sekolah Menengah AtasPerguruan Tinggi).

Berdasarkan hasil analisis bivariat dengan uji chi-square yang dilakukan pada faktor risiko yang diteliti, didapatkan hubungan yang signifikan pada variabel anemia $(p=0,001)$ dan kelainan plasenta $(p=0,049)$ terhadap kejadian BBLR prematur dan dismatur. Pada faktor risiko usia ibu didapatkan nilai $\mathrm{p}$ sebesar 0,713 dimana tidak ada hubungan yang signifikan antara usia ibu dengan kejadian BBLR dismatur dan prematur. Uji variabel lainnya seperti pada faktor risiko untuk paritas $(p=0,160)$, jarak kelahiran $(p=1,000)$, penyakit medis ibu $(p=0,661)$, riwayat obstetris buruk $(p=0,105)$ dan status gizi ibu $(p=0,256)$ dapat dinyatakan tidak terdapat hubungan yang signifikan secara statistik terhadap terjadinya BBLR prematur dan dismatur.

Tabel 3. Analisis bivariat faktor risiko ibu (usia, paritas, jarak kelahiran, anemia, penyakit medis ibu, riwayat obstetrik ibu dan status gizi ibu) dan faktor risiko plasenta terhadap kejadian BBLR prematur dan dismatur di RSUP Dr. M. Djamil Padang periode Januari 2012 - Desember 2012

\begin{tabular}{|c|c|c|c|c|c|c|}
\hline \multirow{2}{*}{\multicolumn{2}{|c|}{ Variabel }} & \multicolumn{4}{|c|}{ BBLR } & \multirow{3}{*}{$p$} \\
\hline & & \multicolumn{2}{|c|}{ Prematur } & \multicolumn{2}{|c|}{ Dismatur } & \\
\hline & & $\mathrm{n}$ & $\%$ & $\mathrm{n}$ & $\%$ & \\
\hline \multirow[b]{2}{*}{ Usia ibu } & Berisiko & 12 & 32,4 & 9 & 25,7 & \multirow[b]{2}{*}{0,713} \\
\hline & $\begin{array}{l}\text { Tidak } \\
\text { berisiko }\end{array}$ & 25 & 67,6 & 26 & 74,3 & \\
\hline \multirow{3}{*}{ Paritas } & $\mathrm{MP}^{*} \&$ & 27 & 73 & 19 & 54,3 & \multirow{3}{*}{0,160} \\
\hline & $\mathrm{GMP}^{* *}$ & & & & & \\
\hline & $\mathrm{PP}^{\star \star \star}$ & 10 & 27 & 16 & 45,7 & \\
\hline \multirow{2}{*}{$\begin{array}{c}\text { Jarak } \\
\text { kelahiran }\end{array}$} & Rapat & 7 & 18,9 & 6 & 17,1 & \multirow{2}{*}{1,000} \\
\hline & Reng-gang & 30 & 81,1 & 29 & 82,9 & \\
\hline \multirow{2}{*}{ Anemia } & Anemis & 21 & 56,8 & 5 & 14,3 & \multirow{2}{*}{0,001} \\
\hline & Tidak anemis & 16 & 43,2 & 30 & 85,7 & \\
\hline \multirow{2}{*}{$\begin{array}{l}\text { Penyakit } \\
\text { medis ibu }\end{array}$} & Ada & 14 & 37,8 & 16 & 45,7 & \multirow{2}{*}{0,661} \\
\hline & Tidak ada & 23 & 62,2 & 19 & 54,3 & \\
\hline \multirow{2}{*}{$\begin{array}{c}\text { Riwayat } \\
\text { obstetris } \\
\text { buruk }\end{array}$} & Ada & 11 & 29,7 & 4 & 11,4 & \multirow[b]{2}{*}{0,105} \\
\hline & Tidak ada & 26 & 70,3 & 31 & 88,6 & \\
\hline \multirow{2}{*}{$\begin{array}{l}\text { Status gizi } \\
\text { ibu }\end{array}$} & KEK & 9 & 24,3 & 4 & 11,4 & \multirow{2}{*}{0,256} \\
\hline & Tidak KEK & 28 & 75,7 & 31 & 88,6 & \\
\hline \multirow{2}{*}{$\begin{array}{l}\text { Kelainan } \\
\text { plasenta }\end{array}$} & Ada & 11 & 29,7 & 3 & 8,6 & \multirow{2}{*}{0,049} \\
\hline & Tidak ada & 26 & 70,3 & 32 & 91,4 & \\
\hline \multirow[b]{2}{*}{ Usia ibu } & Berisiko & 12 & 32,4 & 9 & 25,7 & \multirow[b]{2}{*}{0,713} \\
\hline & $\begin{array}{l}\text { Tidak } \\
\text { berisiko }\end{array}$ & 25 & 67,6 & 26 & 74,3 & \\
\hline \multirow{3}{*}{ Paritas } & $\mathrm{MP}^{*} \&$ & 2710 & 73 & 19 & 54,3 & \multirow{3}{*}{0,160} \\
\hline & $\mathrm{GMP}^{* \star}$ & & & & & \\
\hline & $P P^{\star \star \star}$ & & 27 & 16 & 45,7 & \\
\hline \multirow{2}{*}{$\begin{array}{c}\text { Jarak } \\
\text { kelahiran }\end{array}$} & Rapat & 7 & 18,9 & 6 & 17,1 & \multirow{2}{*}{1,000} \\
\hline & Reng-gang & 30 & 81,1 & 29 & 82,9 & \\
\hline
\end{tabular}

Uji analisis bivariat untuk faktor risiko janin dengan kejadian BBLR prematur dan dismatur dapat dilihat pada Tabel 4 berikut ini. 
Tabel 4. Analisis bivariat faktor risiko janin (jenis kelamin janin, jenis gestasi dan kelainan kongenital) terhadap kejadian BBLR prematur dan dismatur di RSUP Dr. M. Djamil Padang periode Januari 2012 Desember 2012

\begin{tabular}{ccccccc}
\hline \multirow{2}{*}{ Variabel } & \multicolumn{2}{c}{ BBLR } & \multicolumn{2}{c}{ BBLR } \\
& & \multicolumn{2}{c}{ prematur } & \multicolumn{2}{c}{ dismatur } & \multirow{2}{*}{$\mathbf{p}$} \\
\cline { 3 - 6 } & & $\mathbf{n}$ & $\%$ & $\mathbf{n}$ & $\%$ & \\
\hline $\begin{array}{c}\text { Jenis } \\
\text { kelamin } \\
\text { janin }\end{array}$ & Laki-laki & 21 & 56,8 & 23 & 65,7 & \\
\hline Jenis & Perempuan & 16 & 43,2 & 12 & 34,3 & \multirow{2}{*}{0,591} \\
gestasi & Multipel & 5 & 13,5 & 12 & 34,3 & \\
\hline Kelainan & Ada & 1 & 2,9 & 1 & 2,9 & \multirow{2}{*}{1,000} \\
kongenital & Tidak ada & 36 & 97,3 & 34 & 97,1 & \\
\hline
\end{tabular}

Pada analisis statistik didapatkan nilai $p=1,000$ pada kelainan kongenital, $p=0,591$ untuk jenis kelamin janin dan $p=0,072$ pada jenis gestasi yang menyatakan tidak terdapat hubungan yang nyata secara statistik terhadap kejadian BBLR prematur dan dismatur.

Hasil uji bivariat pada faktor risiko lingkungan terhadap kejadian BBLR prematur dan dismatur dapat dilihat pada Tabel 5 berikut ini.

Tabel 5. Analisis bivariat faktor risiko lingkungan (ketinggian tempat tinggal, pendidikan ibu dan status sosioekonomi) terhadap kejadian BBLR di RSUP Dr. M. Djamil Padang periode Januari 2012 - Desember 2012

\begin{tabular}{|c|c|c|c|c|c|c|}
\hline \multirow[t]{2}{*}{ Variabel } & & \multicolumn{2}{|c|}{$\begin{array}{c}\text { BBLR } \\
\text { prematur }\end{array}$} & \multicolumn{2}{|c|}{$\begin{array}{c}\text { BBLR } \\
\text { dismatur }\end{array}$} & \multirow[t]{2}{*}{$\mathbf{p}$} \\
\hline & & $\mathbf{n}$ & $\%$ & $\mathbf{n}$ & $\%$ & \\
\hline \multirow{2}{*}{$\begin{array}{l}\text { Ketinggian } \\
\text { tempat tinggal }\end{array}$} & Berisiko & 3 & 8,1 & 5 & 14,3 & \multirow[b]{2}{*}{0,473} \\
\hline & $\begin{array}{l}\text { Tidak } \\
\text { berisiko }\end{array}$ & 34 & 91,9 & 30 & 85,7 & \\
\hline \multirow{2}{*}{ Pendidikan ibu } & SD-SMP & 17 & 45,9 & 17 & 48,6 & \multirow{2}{*}{1,000} \\
\hline & SMA-PT & 20 & 54,1 & 18 & 51,4 & \\
\hline Status & Rendah & 19 & 51,4 & 19 & 54,3 & \multirow{2}{*}{0,990} \\
\hline sosioekonomi & Tinggi & 18 & 48,6 & 16 & 45,7 & \\
\hline
\end{tabular}

Hasil analisis statistik yang melihat hubungan faktor risiko lingkungan dengan uji chi-square mendapatkan nilai $p=0,473$ pada ketinggian tempat tinggal, $p=1,000$ pada pendidikan ibu dan $p=0,990$ pada status sosioekonomi menggambarkan tidak ada hubungan statistik yang nyata pada masing-masing variabel.

Analisis multivariat dilakukan untuk melihat pengaruh antara beberapa variabel independen dengan variabel dependen. Variabel yang akan dianalisis adalah variabel yang memiliki nilai $p<0,25$ pada analisis bivariate chi-square. Terdapat enam variabel yang memenuhi kriteria analisis multivariat, yaitu paritas, anemia, riwayat obstetris buruk, kelainan plasenta dan jenis gestasi. Hasil dari analisis multivariat tersebut dapat dilihat pada Tabel $6 a$ dan $6 b$ berikut ini:

Tabel 6a. Model awal analisis multivariat uji regresi logistik faktor risiko yang berpengaruh terhahap kejadian BBLR di RSUP Dr. M. Djamil Padang periode Januari 2012 - Desember 2012

\begin{tabular}{|c|c|c|c|c|c|c|}
\hline \multirow{2}{*}{\multicolumn{2}{|c|}{ Variabel }} & \multicolumn{4}{|c|}{ BBLR } & \multirow{3}{*}{ p } \\
\hline & & \multicolumn{2}{|c|}{ Prematur } & \multicolumn{2}{|c|}{ Dismatur } & \\
\hline & & $\mathbf{n}$ & $\%$ & $\mathbf{n}$ & $\%$ & \\
\hline \multirow{3}{*}{ Paritas } & $\mathrm{MP}^{*} \&$ & 27 & 73 & 19 & 54,3 & \multirow{3}{*}{0,14} \\
\hline & $\mathrm{GMP}^{\star *}$ & & & & & \\
\hline & $P P^{* \star *}$ & 10 & 27 & 16 & 45,7 & \\
\hline \multirow[b]{2}{*}{ Anemia } & Anemis & 21 & 56,8 & 5 & 14,3 & \multirow[b]{2}{*}{0,003} \\
\hline & $\begin{array}{c}\text { Tidak } \\
\text { anemis }\end{array}$ & 16 & 43,2 & 30 & 85,7 & \\
\hline \multirow{2}{*}{$\begin{array}{c}\text { Riwayat } \\
\text { obstetris } \\
\text { buruk }\end{array}$} & Ada & 11 & 29,7 & 4 & 11,4 & \multirow{2}{*}{0,263} \\
\hline & Tidak ada & 26 & 70,3 & 31 & 88,6 & \\
\hline \multirow{2}{*}{$\begin{array}{l}\text { Kelainan } \\
\text { plasenta }\end{array}$} & Ada & 11 & 29,7 & 3 & 8,6 & \multirow{2}{*}{0,204} \\
\hline & Tidak ada & 26 & 70,3 & 32 & 91,4 & \\
\hline \multirow{2}{*}{ Jenis gestasi } & Multipel & 5 & 13,5 & 12 & 34,3 & \multirow{2}{*}{0,093} \\
\hline & Tunggal & 32 & 86,5 & 23 & 65,7 & \\
\hline
\end{tabular}

Ket: ${ }^{*} M P=$ Multipara, ${ }^{* \star} G M P=$ Grande Multipara, ${ }^{* * \star} P P=$ Primipara

Tabel 6b. Model akhir analisis multivariat uji regresi logistik faktor risiko yang berpengaruh terhahap kejadian BBLR di RSUP Dr. M. Djamil Padang periode Januari 2012 - Desember 2012

\begin{tabular}{|c|c|c|c|c|c|c|c|}
\hline & & \multicolumn{4}{|c|}{ BBLR } & \multirow{3}{*}{$p$} & \multirow{3}{*}{$\begin{array}{l}\text { Exp } \\
\text { (B) }\end{array}$} \\
\hline \multirow{2}{*}{\multicolumn{2}{|c|}{ Variabel }} & \multicolumn{2}{|c|}{ Prematur } & \multicolumn{2}{|c|}{ Dismatur } & & \\
\hline & & $\mathbf{n}$ & $\%$ & $\mathbf{n}$ & $\%$ & & \\
\hline & $\mathrm{MP}^{*} \&$ & 27 & 73 & 19 & 54,3 & \multirow{3}{*}{0,022} & \multirow{3}{*}{4,503} \\
\hline \multirow[t]{3}{*}{ Paritas } & $\mathrm{GMP}^{* *}$ & & & & & & \\
\hline & $P P^{\star \star \star *}$ & 10 & 27 & 16 & 45,7 & & \\
\hline & Anemis & 21 & 56,8 & 5 & 14,3 & \multirow[b]{2}{*}{0,001} & \multirow[b]{2}{*}{9,844} \\
\hline Anemia & $\begin{array}{c}\text { Tidak } \\
\text { anemis }\end{array}$ & 16 & 43,2 & 30 & 85,7 & & \\
\hline \multirow{2}{*}{$\begin{array}{c}\text { Jenis } \\
\text { gestasi }\end{array}$} & Tunggal & 32 & 86,5 & 23 & 65,7 & \multirow{2}{*}{0,113} & \multirow{2}{*}{0,323} \\
\hline & Multipel & 5 & 13,5 & 12 & 34,3 & & \\
\hline
\end{tabular}

Berdasarkan penelitian ini, ibu yang mengalami anemia saat hamil memiliki risiko 9,844 kali lebih besar untuk melahirkan bayi BBLR dibandingkan 
dengan yang tidak anemia. Ibu multipara dan grandemultipara memiliki risiko 4,503 kali lebih besar dibandingkan ibu primipara untuk melahirkan bayi BBLR. Faktor risiko yang paling dominan terhadap kejadian BBLR adalah anemia dengan nilai $p=0,001$ dan paritas dengan nilai $\mathrm{p}=0,022$ dengan nilai eksponen beta anemia 9,844 dan paritas 4,503 yang didapatkan dari hasil analisis multivariat regresi logistik.

\section{PEMBAHASAN}

Penelitian ini menunjukkan bahwa jumlah kelahiran bayi BBLR prematur dan dismatur hampir sama banyak. Nelson menyebutkan bahwa kejadian BBLR di negara berkembang, termasuk Indonesia, lebih banyak untuk kejadian dismaturitas dibanding prematur. ${ }^{10}$ Berbeda yang ditunjukkan oleh hasil penelitian ini, dimana jumlah dismatur dan prematur hampir sama banyak. Kemungkinan hal ini disebabkan jumlah sampel penelitian yang sedikit akibat banyak yang di eksklusi, selain itu daerah cakupan penelitian yang terbatas untuk ibu-ibu yang melahirkan di RSUP Dr. M. Djamil Padang.

Gambaran distribusi frekuensi untuk kejadian BBLR berdasarkan faktor risiko, didapatkan hanya faktor risiko paritas, jenis kelamin laki-laki dan sosioekonomi yang lebih dari $50 \%$ kejadian BBLR. Untuk faktor lainnya didapatkan persentasi yang bervariasi namun tidak lebih dari $50 \%$, bahkan ada yang $0 \%$ yaitu pada faktor teratogen.

BBLR dengan faktor risiko paritas terjadi karena sistem reproduksi ibu sudah mengalami penipisan akibat sering melahirkan. ${ }^{11} \mathrm{Hal}$ ini disebabkan oleh semakin tinggi paritas ibu, kualitas endometrium akan semakin menurun. Kehamilan yang berulang-ulang akan mempengaruhi sirkulasi nutrisi ke janin dimana jumlah nutrisi akan berkurang dibandingkan dengan kehamilan sebelumnya. ${ }^{7}$ Pada faktor risiko jenis kelamin laki-laki, interaksi antara kebutuhan janin yang besar dengan terjadinya kehamilan yang buruk menimbulkan kecenderungan lebih tinggi untuk bayi laki-laki menderita BBLR setelah lahir. ${ }^{12}$ Pada ibu dengan status sosioekonomi yang baik memungkinkan ibu hamil untuk berada dalam lingkungan yang lebih baik, seperti jauh dari paparan asap rokok dan lain-lain. Hidup dalam keadaan sosioekonomi yang baik juga dapat menjamin kecukupan nutrisi selama hamil untuk mendapatkan hasil akhir janin yang optimal. Selain itu, keadaan sosioekonomi yang baik juga menjauhkan ibu hamil dalam keadaan stres yang dapat mengganggu keseimbangan hormonal ibu. ${ }^{13}$

Saat ini tidak adanya etiologi pasti antara penyebab PJT dan prematuritas, sehingga banyak faktor risiko yang dikemukakan dengan berbagai macam patogenesis yang berkaitan dengan kejadian BBLR. Faktor risiko yang mempengaruhi kedua kejadian tersebut sulit dipisahkan secara tegas dalam kontribusinya sebagai penyebab BBLR. ${ }^{10}$ Penelitian dari Sclowitz et al di Brazil memberikan hasil yang sedikit berbeda dibanding penelitian ini, yaitu persentasi kejadian BBLR yang cukup besar pada ibu yang mengalami anemia $(67,6 \%)$ dan janin dengan jenis kelamin laki-laki (50,8\%). Namun untuk faktor risiko lainnya juga menunjukkan distribusi tidak lebih dari $50 \%$ seperti pada: usia berisiko yaitu $<20$ tahun sebesar $14,5 \%$ dan $>35$ tahun sebesar $13,5 \%$, paritas grandemultipara sebesar $22,3 \%$, riwayat abortus sebanyak $22,7 \%$, pendidikan rendah sebanyak $23,4 \%$, dan status sosioekonomi rendah sebanyak $15,4 \% .{ }^{14}$

Hasil penelitian yang dilakukan oleh Deshpande et al pada 200 sampel ibu yang melahirkan bayi BBLR, dua faktor risiko yang menunjukkan hasil lebih dari 50\% adalah ibu yang memiliki jarak kelahiran <2 tahun (55\%) dan ibu anemia sebesar (55\%). Persentasi kurang dari 50\% didapatkan pada faktor risiko ibu dengan riwayat penggunaan teratogen $(11,5 \%)$ dan ibu memiliki riwayat obstertis buruk (16\%). ${ }^{15}$ Menurut penelitian Mutalazimah yang dilakukan di Surakarta, didapatkan jumlah ibu hamil dengan KEK sebanyak $23,6 \%$ dan anemis sebanyak $30,2 \%{ }^{16}$

Penelitian Roudbari et al yang dilakukan di Iran, didapatkan persentasi kelahiran multipel sebanyak $65,4 \%$ dan ibu dengan penyakit medis sebesar $23 \% .{ }^{17}$ Altuncu et al menyatakan terdapat $1 \%$ ibu yang mengalami plasenta previa, $2 \%$ ibu yang mengalami solusio plasenta dan $1 \%$ ibu yang mengalami KPD (Ketuban Pecah Dini), serta terdapat 6,2\% bayi BBLR yang memiliki kelainan kongenital. ${ }^{18}$ Bayingana mendapatkan $62,2 \%$ ibu bayi BBLR terlahir dari ibu yang hanya menamatkan Sekolah Dasar dan 12\% 
tidak mengikuti pendidikan formal. ${ }^{19}$ Rodriguez et al mendapatkan $34,6 \%$ bayi BBLR yang lahir pada ketinggian tempat tinggal 700 - 999 mdpl dan 2,8\% pada ketinggian $>999$ mdpl pada penelitiannya. ${ }^{20}$

Uji bivariat didapatkan bahwa hubungan yang signifikan $(p<0,05)$ untuk terjadinya BBLR prematur dan dismatur adalah dengan faktor risiko ibu anemia $(p=0,001)$ dan kelainan plasenta $(0,049)$. Kejadian BBLR prematur banyak dilahirkan pada ibu yang mempunyai faktor risiko anemia (56,8\%) dan sebaliknya BBLR dismatur dilahirkan oleh ibu yang tidak anemia (85,7\%). Untuk faktor risiko kelainan plasenta banyak terdapat pada bayi yang BBLR prematur $(70,3 \%)$ dan dismatur $(91,4 \%)$.

Selama masa kehamilan, terjadi anemia relatif pada ibu, yaitu kejadian hemodilusi yaitu penambahan volume plasma relatif yang lebih besar daripada volume sel darah merah. Hemodilusi merupakan suatu adaptasi fisiologis pada sistem sirkulasi ibu hamil untuk memenuhi kebutuhan besar uterus dan janin yang mengalami hipertrofi sistem vaskular. ${ }^{6}$ Normalnya kadar hemoglobin ibu hamil berkisar 12,5 $\mathrm{g} / \mathrm{dl}$ setelah mengalami hemodilusi. Apabila terjadi penurunan kadar hemoglobin hingga dibawah $11 \mathrm{~g} / \mathrm{dl}$, maka hal ini bukan merupakan proses hemodilusi, namun lebih berhubungan dengan kejadian anemia pada ibu hamil. Jenis anemia yang sering terjadi pada ibu hamil adalah anemia defisiensi besi. ${ }^{7}$

Hasil penelitian ini menunjukkan bukti bahwa salah satu dampak anemia pada ibu hamil melahirkan bayi BBLR prematur (56,7\%). Penjelasan dari kejadian ini adalah terjadinya gangguan pertumbuhan janin intra uterin dan persalinan preterm. Ibu hamil yang menderita anemia mengalami persalinan prematur 2,5 kali lebih besar dibandingkan dengan ibu yan tidak anemia. ${ }^{11}$ Anemia dapat mengakibatkan penurunan suplai oksigen ke jaringan, selain itu juga dapat merubah struktur vaskularisasi plasenta, hal ini akan mengganggu pertumbuhan janin sehingga akan memperkuat risiko terjadinya persalinan prematur dan kelahiran bayi dengan berat badan lahir rendah terutama untuk kadar hemoglobin yang rendah mulai dari trimester awal kehamilan. $6,7,11$

Faktor risiko lainnya yang menunjukkan hubungan yang signifikan dengan kejadian BBLR prematur dan dismatur dalam penelitian ini adalah kelainan plasenta, walaupuan persentasi kejadian BBLR prematur dan dismatur dalam penelitian ini tidak terlalu besar. BBLR dengan prematur lebih banyak terjadi dibandingkan dengan BBLR dismatur. Kelainan pada plasenta seperti luas permukaan yang tidak sesuai, kelainan pertumbuhan, infark dan lain lain dapat mengganggu fungsinya dalam menyokong kehidupan janin intrauterin. Hal ini akan menimbulkan dampak buruk pada janin, salah satunya adalah BBLR dengan dismatur. Implantasi plasenta abnormal, seperti plasenta previa berakibat terbatasnya ruang plasenta untuk tumbuh, sehingga akan mempengaruhi luas permukaannya. Pada keadaan ini lepasnya tepi plasenta disertai perdarahan dan terbentuknya jaringan parut sering terjadi, sehingga meningkatkan risiko untuk terjadi perdarahan antepartum. ${ }^{7}$ Apabila perdarahan banyak dan kehamilan tidak dapat dipertahankan, maka terminasi kehamilan harus dilakukan pada usia gestasi berapapun. Hal ini menyebabkan tingginya kejadian prematuritas yang memiliki berat badan lahir rendah disertai mortalitas dan morbiditas yang tinggi. ${ }^{21}$

Kelainan plasenta lainnya adalah solusio plasenta, yaitu merupakan pelepasan plasenta prematur yang terjadi setelah usia kehamilan 20 minggu. Plasenta dengan implantasi normal terlepas sebelum terjadinya partus. ${ }^{22}$ Pelepasan plasenta dapat terjadi disebabkan oleh perubahan vaskularisasi plasenta, trombosis dan perfusi plasenta yang kurang. ${ }^{23}$ Pelepasan plasenta dapat terjadi secara parsial, total dan tersembunyi. Pada pelepasan sebagian dan total, dapat didapatkan manifestasi perdarahan pervaginam merah terang, nyeri punggung, nyeri tekan pada uterus, perut tegang dan kaku dan syok hipovolemik. ${ }^{24}$ Apabila perdarahan yang terjadi banyak dan akut, maka kehamilan tidak dapat dipertahankan, sehingga lebih dari separuh kematian neonatus yang lahir dari ibu dengan solusio plasenta disebabkan oleh prematuritas. Bayi yang lahir dari ibu dengan solusio plasenta memiliki berat badan lahir lebih kecil daripada bayi dengan usia getasi yang sama. Insiden lahir mati atau stillbirth juga tinggi pada solusio plasenta. Pada bayi gestasi tunggal, hal ini dikaitkan dengan PJT kronis dan kelahiran dengan BBLR. $^{23}$ 
Keterbatasan penelitian ini adalah tidak dapat menilai kelainan dari plasenta lainnya seperti infark plasenta dan infeksi plasenta. Infark plasenta dapat menghambat pasokan darah ke janin sehingga dapat mengakibatkan PJT yang terlahir dengan BBLR, asfiksia neonatal bahkan kematian janin. ${ }^{25}$ Infeksi pada plasenta ditandai dengan infiltrasi sel leukosit polimorfonuklear dan mononuklear pada jaringan plasenta. Korioamnionitis merupakan infeksi yang paling sering terjadi pada plasenta selama masa kehamilan. Hal ini biasanya disebabkan oleh ketuban pecah dini yang lama dibiarkan. Ketuban pecah dini adalah pecahnya ketuban pada usia kehamilan kurang dari 37 minggu. ${ }^{6}$

Pada faktor risiko lainnya yang menunjukkan hubungan yang tidak signifikan untuk kejadian BBLR prematur dan dismatur dalam penelitiannya perlu dilakukan penelitian lebih lanjut. Selain itu tidak ditemukan data dari penelitian lainnya yang membahas hubungan antara faktor risiko dengan kejadian BBLR prematur dan dismatur. Salah satu penelitian yang dilakukan Mutalazimah menemukan adanya hubungan yang signifikan antara kejadian BBLR pada anemia pada ibu hamil. ${ }^{16}$ Ramsey et al menemukan hubungan yang signifikan antara kelainan plasenta dengan kejadian BBLR. Kelainan plasenta seperti plasenta previa, solusio plasenta dan KPD berhubungan dengan perdarahan anterpartum, kelahiran preterm dan kegagalan pertumbuhan janin, serta dapat menimbulkan komplikasi lain seperti preeklamsia. ${ }^{27}$ Deshpande et al mendapatkan nilai $p=0,09$ yang manyatakan bahwa tidak terdapat hubungan yang signifikan antara usia ibu dengan kejadian BBLR. Namun masih banyak faktor yang tidak dapat diperkirakan pada wanita yang hamil dan melahirkan pada usia produktif seperti faktor aktifitas fisik dan pekerjaan yang dapat mempengaruhi hasil kehamilan. ${ }^{15}$

Roudbari et al mendapatkan faktor risiko paritas tidak terdapat hubungan yang signifikan dengan kejadian BBLR. ${ }^{17}$ Bayingana juga menunjukkan nilai $p>0,05$ untuk penyakit medis ibu pada uji chi-square dimana tidak didapatkan hubungan yang signifikan secara statistik. ${ }^{19}$ Deshpande et al menemukan hubungan pada analisis bivariat dengan uji chi-square dengan hasil nilai $p$ pada faktor jarak kelahiran dan riwayat obstetris masing-masing sebesar 0,006 dan 0,003 yang menunjukkan adanya hubungan secara statistik, namun pada penelitian ini tidak didapatkan hubungan kedua faktor yang signifikan terhadap kejadian BBLR. Hal-hal ini kemungkinan terjadi akibat adanya pengaruh faktor lain pada populasi yang diteliti. Pengaruh dari keteraturan ANC (Ante Natal Care) dapat mempengaruhi perjalanan penyakit medis pada ibu serta banyak konseling tentang gizi saat hamil dan rencana tidakan persalinan yang dapat diberikan pada ibu dengan riwayat obstetris yang buruk, memiliki paritas tinggi dan jarak kelahiran yang rapat. ${ }^{15}$

Mutalazimah menunjukkan hubungan yang signifikan antara status gizi ibu dan BBLR dengan nilai $p=0,029$, namun pada penelitian ini tidak didapatkan hubungan yang signifikan antara status gizi ibu dan kejadian BBLR. ${ }^{16} \mathrm{Hal}$ ini kemungkinan dapat terjadi karena adanya faktor lain yang ikut serta dalam mempengaruhi kejadian BBLR, seperti pertambahan berat badan ibu selama hamil. Pada wanita KEK yang teratur melakukan ANC, dapat dilakukan konseling untuk mencukupi kebutuhan nutrisi janin selama kehamilan dan dipantau dengan cara lain selain ukuran lingkar lengan atas seperti pertambahan berat badan ibu selama hamil. ${ }^{26}$

Selain ruang lingkup kehidupan janin, potensi tumbuh janin sendiri merupakan hal yang penting dalam pencapaian berat badan lahir. Janin dengan kelainan kongenital, berjenis kelamin laki-laki dan memiliki gestasi multipel dikatakan merupakan faktor risiko pada kejadian BBLR. Roudbari et al menemukan hubungan signifikan antara kejadian BBLR dengan gestasi mutipel. Hal ini kemungkinan dapat terjadi akibat rendahnya angka kejadian gestasi multipel multipel yaitu terjadi antara 3,21 per 1000 kelahiran hidup. ${ }^{17}$ Altuncu et al mendapatkan nilai $\mathrm{p}=0,72$ pada kelainan kongenital dan $\mathrm{p}=0,97$ pada jenis kelamin janin yang menyatakan tidak terdapat hubungan yang signifikan antara keduanya dengan kejadian BBLR. Kelainan kongenital memiliki proporsi yang rendah, yaitu sekitar $3 \%$ dari seluruh kelahiran bayi. Pada masa intrauterin, kelainan ini mengakibatkan kematian pada embrio sekitar $50 \%$. Janin yang bertahan hidup dengan kelainan kongenital memiliki kemungkinan 50 - $60 \%$ untuk mengalami abortus spontan, sehingga 
peluang untuk janin dengan kelainan kongenital lahir lebih sedikit. ${ }^{18}$

Penelitian Rodriguez et al di Spanyol mendapatkan hubungan yang tidak signifikan pada faktor ketinggian tempat tinggal ibu dengan kejadian BBLR. ${ }^{20}$ Roudbari et al mendapatkan nilai $p$ untuk pendidikan ibu sebesar 0,008 dan Deshpande et al mendapatkan nilai $\mathrm{p}$ untuk status sosioekonomi ibu sebesar 0,004 yang menunjukkan hubungan sigifikan secara statistik terhadap kejadian BBLR, namun hubungan nyata secara statistik belum bisa digambarkan pada penelitian ini. Perbedaan hasil yang didapatkan salah satunya dapat terjadi oleh karena perbedaan karakteristik sampel yang diteliti. Penelitian Deshpande et al dilakukan pada daerah pedalaman India, dimana keadaan sosioekonomi rendah ditemukan pada sebagian sampel yang diteliti. ${ }^{15,17}$

Uji multivariat mendapatkan faktor risiko yang mempengaruhi terjadinya BBLR prematur dan dismatur adalah anemia dan paritas banyak,. Berdasarkan penelitian ini ibu yang mengalami anemia saat hamil memiliki risiko 9,844 kali lebih besar untuk melahirkan bayi BBLR prematur dibandingkan dengan yang tidak anemia. Ibu dengan anemia seperti defisiensi besi, mengalami gangguan vaskularisasi plasenta sehingga mengganggu pertumbuhan janin dan dapat melahirkan secara prematur. ${ }^{6}$ Penelitian Asiyah et al juga memperlihatkan hasil lbu hamil yang menderita anemia mengalami persalinan prematur 2,5 kali lebih besar dibandingkan dengan ibu yang tidak anemia. ${ }^{11}$

Faktor multiparitas yaitu ibu multipara dan grandemultipara memiliki risiko 4,503 kali lebih besar dibandingkan ibu primipara untuk melahirkan bayi BBLR prematur. Paritas yang terlampau banyak pada ibu dapat mengakibatkan penurunan kerja sistem reproduksi ibu. ${ }^{11}$ Hasil yang sama diperlihatkan oleh Kumar et al, yaitu kelahiran preterm banyak ditemukan pada paritas $>3$ dengan risiko 0,92 kali lipat dibandingkan paritas $\leq 3 .{ }^{28}$ Menurut penelitian yang dilakukan oleh Ohlsson dan Shah, kematian perinatal meningkat pada paritas empat dan kejadiannya rendah pada paritas dua dan tiga. Risiko lebih tinggi untuk terjadinya PJT juga ditemukan pada ibu dengan paritas lebih dari $5 .{ }^{29} \mathrm{Hal}$ ini disebabkan oleh semakin tinggi paritas ibu, kualitas endometrium akan semakin menurun. Kehamilan yang berulang-ulang akan mempengaruhi sirkulasi nutrisi ke janin dimana jumlah nutrisi akan berkurang dibandingkan dengan kehamilan sebelumnya. ${ }^{7,11}$

\section{KESIMPULAN}

Faktor risiko anemia dan kelainan plasenta memiliki hubungan dengan kejadian BBLR di RSUP Dr. M. Djamil Padang.

Faktor risiko anemia dan paritas merupakan faktor risiko yang paling berpengaruh terhadap kejadian BBLR di RSUP Dr. M. Djamil Padang.

\section{UCAPAN TERIMA KASIH}

Terima kasih kepada para Staff Rekam Medis RSUP Dr. M, Djamil Padang yang telah membantu pengumpulan dan penyediaan data penelitian, selain itu, terima kasih kepada Prof. Dr. dr. Rizanda Machmud, M.Kes yang telah membantu dalam konsultasi statistik penelitian ini.

\section{DAFTAR PUSTAKA}

1. WHO, UNICEF. Low birth weight country, regional and global estimates. New York: WHO; 2004.

2. Kosim MS, Yunanto A, Dewi R, Sarosa GI, Usman A. Buku ajar neonatologi. Edisi ke-1. Jakarta: IDAI; 2012.

3. Dinas Kesehatan. Riset kesehatan dasar. Jakarta: Badan Penelitian dan Pengembangan Kesehatan, Departemen Kesehatan Republik Indonesia; 2010.

4. Dinas Kesehatan. Narasi profil kesehatan Kota Padang Tahun 2011. Padang: Dinas Kesehatan Kota Padang; 2012.

5. Polin RA, Spitzer AR. Fetal and neonatal secrets. Edisi ke-2. Philadelphia: Elsevier; 2007.

6. Cunningham FG, Leveno K, Bloom S, Hauth J, Rouse D, Spong C. Obstetri Williams. Edisi ke- 23. Jakarta: EGC; 2010.

7. Prawirohardjo S. IImu kebidanan. Jakarta: PT Bina Pustaka Sarwono Prawirohardjo; 2008.

8. WHO. Optimal feeding of low birth weight infants. Geneva: WHO; 2006.

9. Deorari AK. Teaching aids on newborn care. 2005 (diunduh 11 Januari 2013) Tersedia dari: URL: HYPERLINK http://www.newbornwhocc.org 
10. Nelson WE. IImu kesehatan anak Nelson Vol. 1. Edisi ke-15. Jakarta: EGC; 2000.

11. Asiyah S, Suwoyo, Mahaendriningtyastuti. Karakteristik bayi berat lahir rendah sampai tribulan II tahun 2009 di Kota Kediri. Jurnal Penelitian Kesehatan Suara Forikes. 2005: 210-22.

12. Legato MJ. Principles of gender specific medicine Edisi ke-2. Philadelphia: Elsevier; 2010.

13. Contrada RJ, Baum A. The handbook of stress science: biology, psychology, and health. New York: Springer Publishing Company; 2011.

14. Sclowitz IKT, Santos IS, Domingues MR, Matijasevich A, Barros AJD. Prognostic factors of low birthweight repetition in successive pregnancies: a cohort study. BMC Pregnancy and Childbirth. 2013:13-20.

15. Deshpande JD, Phalke DB, Bangal VB, Penyuusha D, Sushen B. Maternal risk factors for low birth weight neonates: a hospital based case-control study in rural area of Western Mahastra, India. National Journal of Community Medicine. 2011; 2:394-8

16. Mutalazimah. Hubungan lingkar lengan atas dan kadar hemoglobin ibu hamil dengan berat bayi lahir di RSUD Dr. Moewardi Surakarta. Jurnal Penelitian Sains dan Teknologi. 2005; 6(2):114-26.

17. Roudbari M, Yaghmaei M, Soheili M. Prevalence and risk factors of low birth weight infants in Zahedan, Islamic Republic of Iran. Eastern Mediterranean Health Journal. 2007;13(4):838-45.

18. Altuncu E, Kanvuncuo S, Gokmirza PO, Albayrak $Z$, Arduc A. The incidence of low birth weight in 5000 liveborn infants and the etiology of fetal risk factors. Marmara Medical Journal. 2006; 19(12):46-51.

19. Bayingana C, Muvunyi CM, Africa CWJ. Risk factors of preterm delivery of low birth weight in an african population. Journal of Clinical Medicine and Research. 2011; 2(7):114-8.

20. Rodriguez MD, Perez IR, Gomez OM, Bueno CA, Galvez VB. Risk factors for low birth weight: results from a case-control study in Southern Spain. American Journal of Anthropology. 1998;105:41924.

21. Manuaba IAC, Manuaba IBGF, Manuaba IBG. Gawat darurat obstetri ginekologi dan obstetri ginekologi sosial untuk profesi bidan. Jakarta: EGC; 2008.

22. Morgan G, Hamilton C. Panduan praktik obstetri dan ginekologi. Edisi ke-2. Jakarta: EGC; 2009.

23. Kenner C, Lott JW. Comprehensive neonatal care: an interdisciplinary approach. Philadelphia: Elsevier; 2007.

24. Sinclair C. Buku saku kebidanan. Jakarta: EGC; 2010.

25. Reece EA, Hobbins JC. Clinical Obstetrics The Fetus and Mother. Edisi ke-3. Massachusetts: Blackwell Publishing; 2007.

26. Salmah, Rusmiati, Maryanah, Susanti NN. Asuhan kebidanan antenatal. Jakarta: EGC; 2006.

27. Ramsey P, Andrews W, Faye Petersen O, Cliver S, Goldenberg R, Hauth J. Comparative placental histopathology and microbiology of spontaneous preterm deliver. American Journal of Obstetrics and Gynecology. 2002;187(6).

28. Kumar A, Chaudhary K, Prusad S. Maternal indication and obstetric outcome in the North Indian population: a hospital-based study. J Postgrad Med. 2010;56(3):192-5.

29. Ohlsson A, Shah P. Determinants and prevention of low birth weight: a synopsis of the evidence. Alberta: Institute of Health Economics; 2008. 